\title{
Diplomatic Security for Hire: The Causes and Implications of Outsourcing Embassy Protection
}

\section{Eugenio Cusumano}

Department of International Relations, Leiden University, Leiden, The Netherlands e.cusumano@hum.leidenuniv.nl

Received: 28 July 2015; revised: 11 January 2016; accepted: 5 February 2016

\section{Summary}

The increasing deployment of foreign service officials in fragile and post-conflict environments has enormously magnified the need to protect diplomatic premises and personnel. Consequently, several states have resorted to private security companies (PSCs) as providers of diplomatic protection. As epitomised by the scandals surrounding the United States government's use of armed contractors, however, the privatisation of diplomatic security has often proved problematic. This article analyses the scope, causes and implications of outsourcing diplomatic protection, assessing the extent to which the use of PSCs by the us State Department offers an appropriate response to the need to secure diplomatic personnel in dangerous locations, and providing some policy recommendation on how to improve the effectiveness and accountability of privatised diplomatic protection.

\section{Keywords}

diplomatic security - private security companies (PSCs) - expeditionary diplomacy terrorism - diplomatic inviolability

\section{Introduction}

On 13 April 2015, four private security contractors working for the private security company (PSC) Blackwater Worldwide were convicted by a United 
States (Us) federal court on murder and manslaughter charges. While escorting a Us State Department motorcade through Nisour Square in Baghdad on 16 September 2007, the guards had opened fire against Iraqi civilians, killing fourteen and wounding numerous others. While the contractors claimed that they acted in self-defence, no evidence that the motorcade had come under attack was found. ${ }^{1}$

This verdict marks a turning point in an eight-years-long judicial saga fraught with legal challenges and jurisdiction problems, but does not silence the controversy surrounding the us State Department's use of PSCs. ${ }^{2}$ The Nisour Square shooting was only one of the incidents resulting in Iraqi civilian casualties in which Blackwater was involved. Nor were scandals and misbehaviour unique to Blackwater contractors in Iraq. In 2009, a Us Congressional investigation revealed that alcohol abuse and insufficient training among contractors placed the security of the Us Embassy in Kabul, Afghanistan, at risk. ${ }^{3}$ The selection of poorly trained Libyan guards to protect the Special Mission in Benghazi, Libya, was also forcefully criticised in the wake of the murder of us Ambassador Christopher Stevens on 11 September 2012. ${ }^{4}$

While the outsourcing of Us diplomatic security has become widely publicised, the privatisation of diplomatic security is not unique to the us State Department. In both Iraq and Afghanistan, PSCs have been consistently used as providers of the United Kingdom's diplomatic protection. Canada, Australia, Germany, Sweden and the Netherlands have relied on PSCs to guard

1 Us Federal Bureau of Investigation, 'Four Former Blackwater Employees Sentenced to Decades in Prison for Fatal 2007 Shootings in Iraq', available online at http://www.fbi .gov/washingtondc/press-releases/2015/four-former-blackwater-employees-sentenced-todecades-in-prison-for-fatal-2007-shootings-in-iraq; and Spencer Hsu and Victoria St Martin, 'Four Blackwater Guards Sentenced in Iraq Shootings of $3^{1}$ Unarmed Civilians', The Washington Post (13 April 2015).

2 On the difficulties surrounding the prosecution of private security contractors, see Marcus Edahl, 'Unaccountable: The Current State of Private Military and Security Companies', Criminal Justice Ethics, vol. 31, no. 2 (2012), pp. 175-192; and Micaela Frulli, 'Immunity for Private Military Contractor: Legal Hurdles or Political Snags?', in Francesco Francioni and Natalino Ronzitti (eds), War by Contract (Oxford: Oxford University Press, 2011), pp. 448-469.

3 United States Senate Committee on Homeland Security \& Governmental Affairs Subcommittee on Contracting Oversight, 'New Information about the Guard Contract at the Us Embassy in Kabul' (Washington, DC: us Senate Committee on Homeland Security \& Governmental Affairs, May 2009), pp. i and 4-5.

4 United States Department of State and the Broadcasting Board of Governors Office of Inspector General, Office of Audits, 'Audit of the Department of State Process to Award the Worldwide Protective Services Contract and Kabul Embassy Security Force Task Order', report no. AUD/SI-12-17 (Washington, DC: Us Department of State, December 2011), pp. 11-12. 
their embassies in Kabul. ${ }^{5}$ International organisations such as the United Nations (UN) and the European Union (EU) have also resorted to PSCs to protect their officials operating in sensitive locations. ${ }^{6}$ In sum, the privatisation of diplomatic security is an increasingly widespread practice. Yet the use of armed guards to provide diplomatic protection has frequently proved problematic. Fraud, overbilling and the insufficient staffing, vetting and training of private security guards have not only resulted in wasteful spending, but have also jeopardised the security of diplomatic posts. Moreover, insufficient monitoring, unclear accountability mechanisms and permissive rules for the use of firearms have sometimes translated into abuses and human rights violations. In such cases, the armed protection of embassies and foreign service personnel has undermined the effectiveness of the diplomatic activities that it is intended to enable, thus souring the relationship between the sending states and local societies.

The outsourcing of diplomatic security is a growing phenomenon that has important implications for international security and diplomacy alike. The use of private military and security contractors has received considerable scholarly attention. Very few studies, however, have focused specifically on the privatisation of diplomatic protection. This article provides the first comprehensive examination of the use of PSCS as providers of diplomatic protection. Its aim is neither merely to focus on why diplomatic security has been outsourced, nor to provide a legal analysis of the accountability issues surrounding the use of PSCs, which have both been investigated elsewhere. ${ }^{7}$ By building on the empirical evidence offered by the increasing outsourcing of us diplomatic security, this article seeks to assess whether and to what extent the use of PSCs offers an appropriate response to the need for diplomatic protection, offering some

5 See, for instance, Anna Leander (ed.), Commercializing Security in Europe (New York: Routledge, 2014).

6 Francesco Giumelli and Eugenio Cusumano, 'Normative Power Under Contract? Commercial Support to European Crisis Management Operations', International Peacekeeping, vol. 21, no. 1 (2014), pp. 37-55; and Åse Gilje Østensen, 'UN Use of Private Military and Security Companies: Practices and Policies', SSR Paper no. 3 (Geneva: Democratic Control of the Armed Forces Centre, 2011).

7 On the difficulties surrounding the prosecution of private security contractors, see Edahl, 'Unaccountable', pp. 175-192; and Frulli, 'Immunity for Private Military Contractor', pp. 448-469. On the causes for diplomatic security privatisation in Iraq and Afghanistan, see Eugenio Cusumano and Christopher Kinsey, 'Bureaucratic Interests and the Outsourcing of Security: The Privatization of Diplomatic Protection, in the United States and the United Kingdom', Armed Forces \& Society (2014). 
policy recommendations on how to improve the effectiveness and accountability of commercial diplomatic security providers.

The analysis will mainly focus on Us diplomatic protection in high-risk areas for two main reasons. First, the United States has been at the forefront of the privatisation of armed security and military support at large, and has systematically relied on PSCs for the protection of US diplomatic posts abroad. Second, the United States is the country with the largest diplomatic network, and its embassies and diplomatic personnel have frequently been targeted by terrorist attacks. While only a minority of us diplomatic posts are based in high-risk locations, the concept of expeditionary diplomacy recently embraced by the us State Department has translated into a growing deployment of foreign service personnel in post-conflict environments. Moreover, examining diplomatic security in high-risk areas is important not only because of the especially severe security challenges that it poses, but also because the use of PSCs in countries with weak judicial and law-enforcement capacity may create accountability gaps and increase the risk of abuses against the local population. The protection of Us posts and personnel in dangerous locations is hence a case of intrinsic importance in the study of privatised diplomatic security. ${ }^{8}$ The analysis will be based on official documents that were produced in the wake of the latest incidents and investigations, complemented by a set of semi-structured interviews with foreign service personnel, Diplomatic Security Bureau officials and private security contractors that were conducted between 2012 and 2015 .

The article is divided as follows. The first section introduces the concept of diplomatic inviolability, illustrating how the rise of international terrorism and the increasing deployment of foreign service personnel in dangerous locations have enormously magnified the need for diplomatic security. The second section provides an overview of diplomatic security policies worldwide, analysing the growing role of PSCs as providers of diplomatic protection. The third and fourth sections turn to us diplomatic security policies, focusing on the increasing resort to PSCs and the main reasons underlying their use. The conclusions critically review the implications of outsourcing diplomatic protection, assessing whether PSCs offer a viable solution to the increasing demand for diplomatic security and providing some policy recommendations.

8 On intrinsic importance as a criterion for case selection, see Steven van Evera, Guide to the Methods in the Social Sciences (Ithaca, NY: Cornell University Press 1997), pp. 86-87. 


\section{Diplomatic Security: An Overview}

The inviolability of diplomatic personnel and premises is a cornerstone of inter-state relations. Still, as this section briefly explains, diplomatic posts and personnel have grown increasingly vulnerable to terrorism and political violence.

Long enshrined in customary international law, the principle of diplomatic inviolability has been codified by the 1961 Vienna Convention on Diplomatic Relations and the 1963 Vienna Convention on Consular Relations. The norm of diplomatic inviolability not only exempts diplomatic personnel from 'any form of arrest or detention', but it also imposes on the host state a 'special duty to protect the premises of the mission against any intrusion or damage', taking 'all appropriate steps to prevent any attacks on [diplomats'] person, freedom or dignity'. ${ }^{9}$ The 1973 Un Convention on the Prevention and Punishment of Crimes Against Internationally Protected Persons Including Diplomatic Agents has further strengthened diplomatic inviolability, by requiring signatories to take all practicable steps to prevent the perpetration and ensure the prosecution of crimes against diplomats. ${ }^{10}$ A 1980 Un General Assembly Resolution further emphasises 'the importance of inviolability [...] as a basic prerequisite for the normal conduct of relations among states', urging 'all States to effectively ensure $[. .$.$] the protection, security and safety of diplomatic and$ consular missions and representatives.'1 ${ }^{11}$ The large numbers of ratifications for the 1961 Vienna Convention and the 1973 UN Convention, respectively 189 and 176 , forcefully illustrate the strength of the norm of diplomatic inviolability. ${ }^{12}$ The unanimous stigma surrounding the 1979 takeover of the Us Embassy in Iran - which stands out as a nearly unique violation of diplomatic inviolability openly supported by a state - further demonstrates the strong belief in the host state's obligation to protect foreign dignitaries.

While diplomatic inviolability remains a lynchpin of inter-state relations, non-state threats against the physical safety of foreign service personnel have

9 Vienna Convention on Diplomatic Relations, art. 22-29. See also Linda Frey and Marsha Frey, The History of Diplomatic Immunity (Columbus, он: Ohio State University Press, 1999).

10 United Nations General Assembly, 'Convention on the Prevention and Punishment of Crimes against Internationally Protected Persons, including Diplomatic Agents', Annexe to General Assembly Resolution 3166 (XVIII) of 14 December 1973.

11 United Nations General Assembly Resolution 35/168, 'Consideration of Effective Measures to Enhance the Protection, Security and Safety of Diplomatic and Consular Missions and Representatives' of ${ }_{15}$ December 1980.

12 Clive J. Barker, The Protection of Diplomatic Personnel (Farnham: Ashgate, 2006). 
proliferated over recent decades. The rise of terrorism and the expansion of diplomatic activities in countries suffering from severe political violence have translated into a considerable increase in diplomatic protection challenges, forcing sending states to devise a number of additional security measures to complement host-country support. ${ }^{13}$ The role played by the Us State Department in supporting the reconstruction of Iraq and Afghanistan from 2003 onwards, enshrined by the concept of 'transformational diplomacy, ${ }_{1}^{14}$ further magnified the need for diplomatic security. While reformulated as 'expeditionary diplomacy', the deployment of us diplomatic personnel to weak and fragile states did not stop under the Obama administration. By 2010, the US expeditionary diplomacy concept had translated into the detachment of over 25 per cent of foreign service personnel to posts located in the 30 highest-risk countries..$^{15}$ us State Department funding, however, failed to match the new challenges arising from expeditionary diplomacy. ${ }^{16}$

TABLE 1 Attacks against Us diplomatic facilities and personne l17 $^{17}$

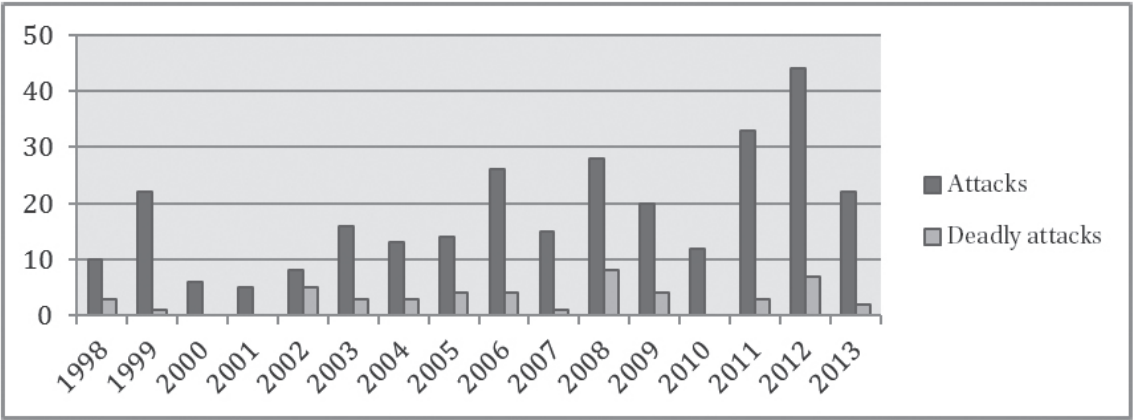

13 Geoffrey R. Berridge, The Counter-revolution in Diplomacy and Other Essays (Houndmills: Palgrave Macmillan 2011).

14 Justin Vaisse, 'Transformational Diplomacy', European Union Institute for Security Studies Chaillot Paper no. 103 (Paris: EuIss, June 2007).

15 Us State Department, 'Leading Through Civilian Power', Quadrennial Diplomacy and Development Review (Washington, DC: Us State Department, 2010), p. 122.

16 Anthony Cordesman, The Death of Ambassador Chris Stevens: The Need for "Expeditionary Diplomacy" and the Real Lessons for us Diplomacy (Washington, DC: Center for Strategic and International Studies, October 2012).

17 The figures are drawn from us Department of State Bureau of Diplomatic Security, 'Significant Attacks against us Diplomatic Facilities and Personnel' (Washington DC: us Department of State, 2013). 
The proliferation of attacks against us diplomatic facilities and personnel forcefully reflects the security challenges posed by international terrorism and expeditionary diplomacy. Between 1998 and March 2013, as illustrated in Table 1, the Us State Department Diplomatic Security Bureau reported 273 'significant' attacks, 46 of which resulted in casualties among bystanders, diplomatic security personnel, or us officials.

While the expeditionary diplomacy activities carried out in the wake of the invasion of Iraq and Afghanistan magnified diplomatic security challenges, attacks against diplomatic personnel and premises are not a novelty. As often stated by us State Department officials to stress the importance of diplomatic security, the United States lost more ambassadors than generals. ${ }^{18}$ Between 1977 and 2014, 66 us State Department officials were killed in terrorist attacks. ${ }^{19}$ During the 196os already, Marxist terrorist groups in South and Central America consistently resorted to the kidnapping and murder of Us diplomats. In 1968, us Ambassador to Guatemala John Gordon Mein was killed. One year later in 1969, Us Ambassador to Brazil Charles Burke Elbrick was kidnapped, followed in 1973 by us Ambassador to Haiti Clinton Everett Knox. ${ }^{20}$ The Middle East and Africa proved even more dangerous for us diplomatic personnel. In 1973, Us Ambassador to Sudan Cleo Allen Noel was kidnapped and killed by the Palestinian terrorist organisation Black September; and Francis Meloy, the Us Ambassador to Lebanon, was murdered in $1976 .{ }^{21}$ Bombings proved to be the most effective strategy to hit diplomatic posts. The attacks against the Us Embassy in Lebanon in 1983 and 1984, and in Kenya and Tanzania in 1998, imposed a heavy death toll, informing major reforms in us diplomatic security policies. ${ }^{22}$

Although us posts and personnel have been targeted most frequently, diplomatic security is not a uniquely American challenge. As another country that is especially vulnerable to terrorism, Israel has repeatedly suffered from terrorist attacks against its embassies and consulates in South America, Asia and

\footnotetext{
18 Author's interview with a regional security officer.

19 Alex Tiersky and Susan Epstein, 'Securing us Diplomatic Facilities and Personnel Abroad: Background and Policy Issues', Report to Congress (Washington, DC: Congressional Research Service, 28 May 2014).

20 Carol Baumann (ed.), The Diplomatic Kidnappings: The Revolutionary Tactic of Urban Terrorism (Amsterdam: Martinus Nijhoff, 1973).

21 Richard Clutterbuck, Kidnap, Hijack and Extortion (London: Macmillan, 1987).

22 us State Department, The History of the Bureau of Diplomatic Security of the United States' Department of State (Washington, DC: Global Publishing Solutions, 2011).
} 
Europe alike. ${ }^{23}$ Throughout the 1980 os and 1990s, French diplomatic personnel were murdered in Lebanon, Algeria and the Democratic Republic of Congo. ${ }^{24}$ In 2003, a car bomb placed in front of the British Consulate in Istanbul, Turkey, killed 27 people, including Uk Consul General Roger Short. ${ }^{25}$ Also in 2003, the bombing of the United Nations' headquarters in Baghdad, Iraq, killed 22 people, including Un Special Representative Sergio Vieira de Mello. A 2011 car bomb attack at the UN's headquarters in Abuja, Nigeria, also killed 21 UN employees. ${ }^{26}$

As illustrated above, providing effective diplomatic security has become increasingly challenging. The next section will examine the institutional arrangements and actors involved in the provision of diplomatic protection.

\section{Diplomatic Security Policies Examined}

The expansion of diplomatic activities worldwide and the rise of international terrorism have enormously increased the need for diplomatic security. As stated in the Vienna Convention, responsibility for protecting foreign dignitaries lies primarily within host countries. Advanced states with a global embassy and consular presence, however, have responded to the growing need for diplomatic protection in various ways, complementing host nations' protection forces with various security measures, ranging from the use of their own military and police forces to resorting to local and international PSCs.

States with sizeable military police forces have frequently relied on such bodies for the protection of their diplomatic posts. France, for instance, has traditionally deployed its Gendarmerie to protect foreign missions abroad. Italy usually detaches units from its military police, the Carabinieri, to perform diplomatic protective duties abroad. ${ }^{27}$ Germany has resorted to its Bundespolizei

23 Israel Security Agency Terror Data and Trend Archive, available online at http://www .shabak.gov.il/English/EnTerrorData/Archive/Pages/default.aspx.

24 '20 millions d'euros pour renforcer la sécurité des diplomates français', Le Figaro (22 May 2013).

25 Barker, The Protection of Diplomatic Personnel.

26 UN News Centre, available online at http://www.shabak.gov.il/English/EnTerrorData/ Archive/Pages/default.aspx; 'Nigerian Authorities Seek Alleged Mastermind of Deadly un Headquarters Bombing', The Washington Post (18 September 2011).

27 Cusumano and Kinsey, 'Bureaucratic Interests and the Outsourcing of Security'; Barker, The Protection of Diplomatic Personnel. 
for the performing of diplomatic protective duties, which are usually conducted by the personal protection unit of the elite corps GSG $9 .{ }^{28}$

The United Kingdom, too, has traditionally resorted to the Royal Military Police (RмP) to protect embassies and diplomatic personnel abroad. ${ }^{29}$ However, the small size of the RMP - which only comprises 2,500 personnel urged UK decision-makers to resort to alternative solutions. During the 1990s already, the use of RMP units for the close protection of foreign service personnel had to be restricted to the five highest-threat locations. Consequently, PSCs started to be sporadically used already before $9 / 11$. This trend was expanded in the wake of the occupation of Iraq and Afghanistan, where the RMP was only capable of providing close protection for UK ambassadors. As a result, PSCs such as ArmorGroup (now G4S), Control Risks Group and GardaWorld were used for activities such as guarding embassies and for close protection of lower-ranking British Foreign \& Commonwealth Office and Department for International Development personnel. ${ }^{30}$

Canada, too, while generally resorting to the Canadian Forces Military Police, has routinely outsourced diplomatic security activities, spending around CAN\$ 35 million per year to protect its embassy in Kabul between 2006 and $2008 .{ }^{31}$ Australia — which has no expeditionary police body — has systematically outsourced the protection of its diplomatic personnel in Baghdad, Kabul and other locations to PSCs, which in 2011 even protected then Foreign Minister Kevin Rudd during his visit to Libya. ${ }^{32}$ Several other European countries, such as Germany, Sweden and the Netherlands, have resorted to armed contractors for the static protection of their embassies in Afghanistan. ${ }^{33}$

The outsourcing of static and personal security is also increasingly widespread among international organisations. The UN, for instance, has

28 Martin Kügele, 'Personenschutz Ausland der Bundespolizei', Bundespolizei kompakt, vol. 41, no. 2 (2014), pp. 16-19.

29 Eric Morris and Alan Hoe, Terrorism: Threat and Response (London: Macmillan, 1987).

30 Author's interviews with FCO and DfID personnel; Christopher Kinsey, Private Contractors and the Reconstruction of Iraq (New York: Routledge, 2009).

31 David Perry, "The Privatization of the Canadian Military: Afghanistan, Canada First and Beyond', International Journal, vol. 64, no. 3 (2009).

32 James Brown, 'Guns for Hire: The Surprising Role of Australians in the Rise of Private Security Companies', The Monthly (May 2014), available online at http://www.themonthly .com.au/issue/2014/may/139886640o/james-brown/guns-hire.

33 Leander (ed.), Commercializing Security; Guido Den Dekker, 'The Netherlands', in Christine Bakker and Mirko Sossai (eds), Multilevel Regulation of Private Military and Security Contractors (Oxford: Hart, 2013), pp. 253-273. 
consistently relied on PSCs for the protection of its premises and personnel. ${ }^{34}$ The EU has also been increasingly reliant on armed contractors. Immediately after the creation of the European External Action Service (EEAS), the protection of EU posts in theatres such as Libya, Yemen, the Palestinian Territories and Afghanistan was contracted out to four private security companies: $\mathrm{G}_{4} \mathrm{~S}$, Argus, Geos, and Page. The use of Pscs by the EU generated heated controversy. Alleged abuses by the personnel of Page International in both the Palestinian Territories and Afghanistan, for instance, resulted in interrogations from the European Parliament and strong criticism against the EEAS securityoutsourcing policy. ${ }^{35}$

This section has introduced a comparative dimension to the study of diplomatic security by briefly examining diplomatic security arrangements across European countries and international organisations. The next section turns to an in-depth investigation of Us diplomatic security policies.

\section{The us Approach to Diplomatic Security}

While the use of armed contractors has gained momentum both among states and international organisations, the United States has unquestionably been at the forefront of the security privatisation trend.

us diplomatic protection has been based on different institutional frameworks and conducted by different agencies. As remarked by the Us State Department's Diplomatic Security Bureau:

A host country's protection of an American embassy or other diplomatic facilities is one of the most important elements of security at that facility, but it is not the only one. A facility's own security, such as its Us Marine Corps Security Guards, Ds [Diplomatic Security] agents, and in some cases private security guards under contract, is also critical to its overall security posture. ${ }^{36}$

After the Second World War, when us diplomatic presence worldwide expanded dramatically, the Us State Department reached an agreement

34 Østensen, 'Un Use of Private Military and Security Companies'.

35 Giumelli and Cusumano, 'Normative Power under Contract?'.

36 United States Senate Committee on Homeland Security and Governmental Affairs, 'Flashing Red: A Special Report on the Terrorist Attack at Benghazi' (Washington, DC: us Senate, 30 December 2010). 
with the Marine Corps for the protection of Foreign Service posts through a Marine Embassy Security Guard programme, which was established in 1947. The programme, however, remained limited in size and largely confined to the protection of sensitive information. ${ }^{37}$ The Accountability Review Board that was summoned in the wake of Ambassador Christopher Stevens' murder in Benghazi called for a substantial expansion of the Marine Security Guard force. This has led to the creation of 50 new Marine Security Guard units to fill us diplomatic security gaps worldwide. Moreover, a 120-men Marine Embassy Augmentation Unit was created in order to provide embassies worldwide with the possibility of temporarily augmenting their security personnel in case of need. ${ }^{38}$ In addition to the Embassy Security Guard programme, the Marine Corps has also been involved in the provision of emergency response and the evacuation of us embassies through its Fleet Antiterrorism Security Teams (FAST) ${ }^{39}$

While the Marine Corps has played a significant role in securing us embassies and diplomatic cables, the protection of us diplomatic personnel has traditionally been — and will to a large extent remain — performed in-house by the us State Department. Even when the attacks against the us Embassy in Lebanon in 1983 and 1984 called into question the State Department's ability to perform diplomatic security effectively, us State Department officials insisted on remaining in charge of diplomatic security. ${ }^{40}$ The 1986 Omnibus Diplomatic Security and Antiterrorism Act, which was enacted after the attacks in Beirut, expanded the State Department Security Office into a larger Diplomatic Security Bureau (DS). Primary responsibility for protecting us missions and personnel was assigned to the Diplomatic Security Service (DSS), a law enforcement agency staffed with us federal agents who were also in charge of protecting foreign dignitaries and conducting visa fraud investigations within the United States. ${ }^{41}$ After the 1998 attacks against the embassies in Nairobi and Dar es Salaam, the DSs expanded to more than 1,00o personnel, and grew further to about 1,450 agents after 9/11. As of 2013, Dss staffing encompassed more than 2,000 permanent personnel. ${ }^{42}$

\footnotetext{
37 Us State Department, The History of the Bureau of Diplomatic Security, pp. 101-103.

38 Tiersky and Epstein, 'Securing us Diplomatic Facilities and Personnel Abroad', p. 7.

39 Author's interview with retired us ambassador; and author's interview with regional security officer.

40 James Q. Wilson, Bureaucracy (New York: Basic Books, 1989).

41 United States Bureau of Diplomatic Security, The History of the Bureau of Diplomatic Security, pp. 300-301.

42 Tiersky and Epstein, 'Securing us Diplomatic Facilities and Personnel Abroad', p. 5.
} 
In spite of its enlargement, however, the Dss remained too small to conduct the entire range of diplomatic security tasks that were required in the wake of the occupation of Iraq and Afghanistan. Over the last two decades, State Department funding has suffered from a sharp decline. Budgetary allocations for diplomatic security often proved insufficient to cover the growing magnitude of diplomatic security challenges. Before the 1998 attacks in Kenya and Tanzania, for example, funding for diplomatic security was substantially reduced. As noted by the subsequent Accountability Review Board, federal diplomatic security allocations tend to follow a 'boom and bust' cycle, growing abruptly in the wake of a major incident and then shrinking again in the following years. ${ }^{43}$ Erratic, one-off funding has also been blamed as a major impediment to effective diplomatic security planning in the investigations following the 2012 attack against the us Special Mission in Benghazi. ${ }^{44}$ As illustrated in Table 2, us diplomatic security budgets have grown over recent years. Congressional diplomatic security allocations peaked at over us \$ 4 billion in 2012 and 2013, when new security measures were devised in response to the murder of Ambassador Stevens. ${ }^{45}$

TABLE 2 Diplomatic security funding allocations (in millions of US\$)

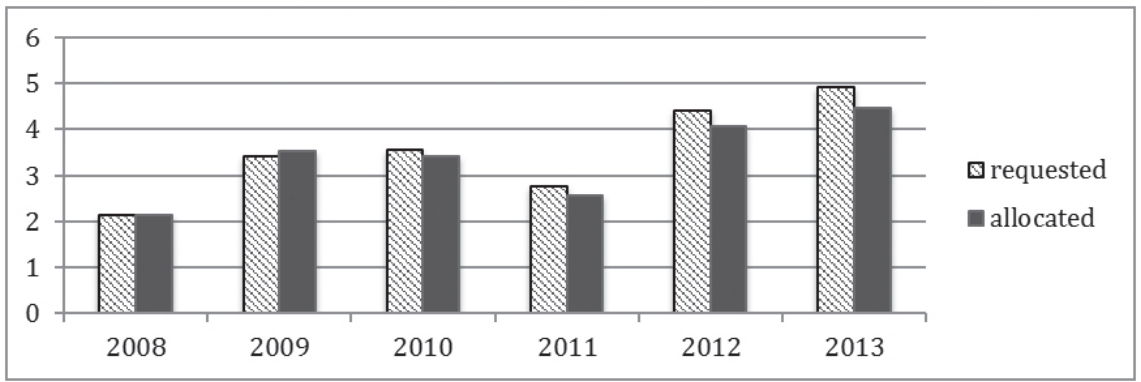

43 Report of the Accountability Review Boards on the Embassy Bombings in Nairobi and Dar el Salaam on 7 August, 1998 (Washington, DC: Us State Department, January 1999).

44 Tiersky and Epstein, 'Securing us Diplomatic Facilities and Personnel Abroad', p. 2.

45 Susan Epstein, Alex Tiersky and Marian Lawson, 'State, Foreign Operations, and Related Programs: FY2014 Budget and Appropriations', Report for Congress (Washington, DC: Congressional Research Service, 16 January 2014). 


\section{The Rise of Private Diplomatic Security Providers}

The mismatch between growing diplomatic security challenges and the insufficiency of the us State Department's diplomatic security budgets and personnel, as illustrated in the previous section, is vital for explaining the increasing use of private security contractors, which now make up the most sizeable component of the Us diplomatic protection workforce. As of 2007, the US State Department employed PSCs in 155 diplomatic posts in 111 countries worldwide. ${ }^{46}$ Contractors now account for roughly go per cent of the Diplomatic Security Bureau's workforce, amounting to no less than 30,000 guards. ${ }^{47}$ This section analyses the use of PSCs by the Us State Department.

Private guards were already sporadically used to protect us embassies before the Second World War. ${ }^{48}$ Now hired through the Local Guard Program, private security personnel who are citizens of the host country can be employed for either armed or unarmed access control, building and residence security. Until 2008 , contracts with local private security firms were negotiated and signed independently by each diplomatic post following federal procurement templates. The procedure, however, has now been centralised under the State Department Bureau of Administration Office of Acquisitions Management in Washington, DC, which awards contracts in consultation with the Regional Security Officer and Chief of Missions of the posts in need of protection..$^{49} \mathrm{In}$ 2011, the Office of Acquisition Management was administering 88 local guarding contracts, for a total value of around u $\$ 500$ million. ${ }^{50}$ Wherever possible, local guards are preferred over us or third-country nationals for two main reasons: first, local guards provide a cheaper and more low-key form of protection; and second, resorting to locals guarantees a clearer legal framework, and does not require arrangements such as the inclusion of foreign contractors in a Status

46 Nathan Hodge, Armed Humanitarians (New York, NY: Bloomsbury, 2011), p. 30.

47 us House of Representatives, 'Blackwater USA: Hearing before the Committee on Oversight and Government Reform' (Washington, DC: Government Printing Office, October 2007), p. 140.

48 United States Bureau of Diplomatic Security, The History of the Bureau of Diplomatic Security, p. 46.

49 Us Department of State Foreign Affairs Manual, volume 12, handbook 7: 'Local Guard Program Handbook' (undated).

5o United States Department of State and the Broadcasting Board of Governors Office of Inspector General Office of Audits, 'Review of Best-Value Contracting for the Department of State Local Guard Program and the Utility of Expanding the Policy Beyond High-Threat Posts in Iraq, Afghanistan, and Pakistan', report no. AUD/CG-12-27 (February 2012). 
of Forces Agreement (SOFA). ${ }^{51}$ As host countries are often unwilling to sign agreements that exempt foreign workers from local jurisdiction, the inclusion of contracted personnel into SOFAs has proved to be problematic. For instance, extension of 'the privileges and immunities accorded to that diplomatic mission' to Us technical personnel granted by the 1961 Us-Iran economic assistance agreement was used by Ayatollah Ruhollah Khomeini to rally Iranians against the us diplomatic presence, and was one of the grievances that eventually culminated in the takeover of the us Embassy in Tehran after the Iranian Revolution. ${ }^{52}$ More recently, the exemption of international PSCs from Iraqi jurisdiction granted by the 2003 Coalition Provisional Authority Order no. 17 and the 2006 SOFA soured the relationship between the United States and Iraq, ultimately preventing the us government from keeping a larger military presence after the end of operation Iraqi Freedom in 2011..$^{53}$

While it minimises frictions with host states and jurisdiction problems, resorting to local guards has frequently been ineffective. A 2012 survey among us embassy personnel revealed problems with many local guarding contracts. According to 40 per cent of respondents, contractors suffered from insufficient training. Moreover, 27 per cent complained about absenteeism and insufficient numbers of guards. ${ }^{54}$ In high-threat environments, the crucial importance of high professional standards and the impossibility of properly vetting local personnel do not allow for the use of local guards, requiring the deployment of us or third-country contractors to provide personal security services. Private security teams tasked with providing mobile security for us diplomatic personnel were first deployed to Haiti in 1994, and then to Bosnia in $1995 .{ }^{55}$ After the spike in the demand for diplomatic protection following the 1998 attacks in Kenya and Tanzania, the Bureau of Diplomatic Security devised the first Worldwide Personal Protective Services (WPPS) contract, which provided the possibility to deploy armed contractors systematically for the personal protection of us State Department officials abroad. Awarded to Dyncorp, the first WPPS contract covered protective security services in former Yugoslavia and

$5^{1} \quad$ Author's interview with regional security officer; and author's interview with retired diplomatic security special agent.

52 Roy Parviz Mottahedeh, 'Iran's Foreign Devils', Foreign Policy, no. 38 (spring 1980), p. 25.

53 Sean McFate, The Modern Mercenary (Oxford: Oxford University Press, 2015); Cusumano and Kinsey, 'Bureaucratic Interests and the Outsourcing of Security'.

54 United States Department of State and the Broadcasting Board of Governors Office of Inspector General Office of Audits, 'Review of Best-Value Contracting for the Department of State Local Guard Program', p. 9. us State Department, The History of the Bureau of Diplomatic Security, p. 343. 
the Palestinian Territories and the protection of President Hamid Karzai in Afghanistan. ${ }^{56}$

\section{Private Diplomatic Security in Iraq}

In 2004, the establishment of a new US Embassy in Baghdad and the protection of Us Ambassador John Negroponte as well as a growing number of State Department personnel who were deployed to Iraq enormously increased the demand for armed protection. As Dyncorp alone was unable to meet the us State Department's request, the protection of State Department personnel in Baghdad and central Iraq was awarded to Blackwater, which had already been involved in the provision of security for the Head of the us Coalition Provisional Authority Paul Bremer. ${ }^{57}$ Another firm, Triple Canopy, was given the task of protecting the us Embassy office in Basra. In 2005, a second WPPS contract was awarded jointly to Blackwater, DynCorp and Triple Canopy. Blackwater - which received some us\$ 340 million per year in exchange for its protective services - took the lion's share of Iraq's diplomatic security assignments, dwarfing the pay-outs to Dyncorp and Triple Canopy, which amounted to US $\$ 47$ and US $\$ 15$ million per year respectively.58

PSCs proved capable of effectively protecting us diplomatic personnel in Iraq. As often remarked by private security advocates, no us official protected by Blackwater was ever murdered or seriously injured..$^{59}$ By September 2007, however, the problematic implications of privatised diplomatic security in Iraq became apparent. The Nisour Square incident resulted in a us military investigation and a subsequent Congressional Hearing that brought Blackwater's conduct under the spotlight, revealing that several problems and incidents had already occurred before late 2007. While escorting diplomatic motorcades, Blackwater contractors frequently drove their convoys at high speed through Baghdad's busy streets, bumping Iraqi cars out of the road and pre-emptively shooting at suspect targets. These procedures were consistent with the US State Department's provisions. State Department protocols envisaged an

56 Cusumano and Kinsey, 'Bureaucratic Interests and the Outsourcing of Security'.

57 United States Department of State and the Broadcasting Board of Governors Office of Inspector General, 'Joint Audit of Blackwater Contract and Task Orders for Worldwide Personal Protective Services in Iraq', report no. AUD/IQO-09-16 (Washington, DC: us State Department, June 2009), p. 5 .

58 Erik Prince, Civilian Warriors: The Inside Story of Blackwater and the Unsung Heroes of the War on Terror (New York: Penguin, 2013), pp. 169-170.

59 Author's interviews with private security industry representative; author's interview with regional security officer; and author's interview with retired us ambassador. 
escalation-of-force policy that was referred to as the 'use of force continuum', consisting of a series of visual and acoustic warnings that would finally culminate in pre-emptive fire against the radiator and the windshield of vehicles that came too close to diplomatic motorcades. In some circumstances, however, 'deadly force' could be immediately applied short of any warning. ${ }^{60}$ As further explained by the Department of State's Deadly Force and Firearms Policy and the us Embassy of Baghdad's Mission Firearms Policy:

[...] the necessity to use deadly force arises when all other available means of preventing imminent and grave danger have failed or would be likely to fail. [...] Determining whether deadly force is necessary may involve instantaneous decisions that encompass many factors, such as the likelihood that the object will use deadly force. ${ }^{61}$

Such procedures, which ultimately allowed for the pre-emptive use of lethal force based on an ill-specified criterion of necessity, were deemed necessary because of the danger created by the insurgency and especially by suicide car bombers, which made all vehicles approaching diplomatic convoys a potential threat to Us officials' safety. ${ }^{62}$

Aggressive, fast driving through crowded roads and the possibility of using pre-emptive force inevitably translated into collateral damage well before Nisour Square. In June 2005, a Blackwater contractor accidentally killed an innocent bystander in Al-Hillah, south of Baghdad. Even if the Blackwater personnel involved 'failed to report the shooting and covered it up', the us State Department did not open any investigation, only recommending that Blackwater pay us $\$ 5,000$ to the family to 'put this unfortunate matter behind us quickly'. In at least two other later cases, Blackwater contractors' use of firearms resulted in the killing of Iraqi civilians. In each of these circumstances, the us State Department authorised Blackwater to transport the responsible contractors out of Iraq, only recommending a 'sizeable payment' to the victims' families and an 'apology to avoid this whole thing becoming even worse'.63

6o Us Department of State, 'Report of the Secretary of State's Panel on Personal Protective Services in Iraq' (hereafter Blackwater Hearing) (Washington, DC: us State Department, 2007), p. 135.

61 Prince, Civilian Warriors, p. 213.

62 Author's interview with private security industry representative; and author's interview with us State Department regional security officer.

63 James Risen, 'Before Shooting in Iraq, a Warning on Blackwater', The New York Times (29 June 2014). 
Blackwater contractors' aggressiveness was not limited to escorting diplomatic motorcades. On Christmas Eve 2006, a drunk Blackwater armourer shot and killed a guard of the Iraqi Vice-President. ${ }^{64}$ In early 2007, a us State Department memo concluded that Blackwater contractors 'saw themselves as above the law', depicting the us Embassy in Iraq as an environment where 'the contractors, instead of Department officials, are in command and control. ${ }^{65}$ One of the officials who wrote the memo also reported death threats by Blackwater's project manager in Iraq, who allegedly said 'he could kill [him] at that very moment and no one could or would do anything about it as we were in Iraq'. Far from finding support from us diplomatic personnel at the Embassy in Baghdad, the authors of the inquiry were criticised for creating 'an unnecessarily hostile environment for a number of contract personnel' and for disrupting the working relationship between Blackwater and us Embassy personnel. As a result, the investigators left the country and their memo fell on deaf ears. ${ }^{6}{ }^{6}$ A few months later, the Nisour Square shooting occurred.

As epitomised by the evidence above, aggressiveness and the excessive use of lethal force did not just occur as isolated cases, but were a systemic problem. Between 2005 and 2007, Blackwater personnel fired their weapons 323 times. ${ }^{67}$ According to some scholars, Blackwater's organisational culture created a permissive environment for aggressive behaviour. The other firms involved in the protection of us diplomats in Iraq, by contrast, fired their weapons much less frequently. 68 The extent to which this was because of greater restraint or because of the much smaller number of escorting missions and the more benign environments in which Triple Canopy and Dyncorp were operating, however, remains contentious. To be sure, the problems were not unique to Blackwater. Triple Canopy, for instance, faced a lawsuit by two former employees who claimed that they had been dismissed for reporting the use of firearms against Iraqi civilians. While the lawsuit turned in favour of Triple Canopy, the jury also stated that the firm's 'poor conduct, lack of standard reporting procedures, bad investigation methods and unfair double standards amongst employees should not be condoned, ${ }^{69}$

\footnotetext{
64 Blackwater Hearing, pp. 3 and $57-58$.

65 Risen, 'Before Shooting in Iraq, a Warning on Blackwater'.

66 Risen, 'Before Shooting in Iraq, a Warning on Blackwater'.

67 Scott Fitzimmons, 'Wheeled Warriors: Explaining Variations in the Use of Violence by Private Security Companies in Iraq', Security Studies, vol. 22, no. 4 (2013), p. 709.

68 Fitzsimmons, 'Wheeled Warriors', p. 709; see also Prince, Civilian Warriors.

69 Zachary A. Goldfarb, 'A Tougher line on Government Contracting', The Washington Post (8 October 2007), available online at http://www.washingtonpost.com/wp-dyn/content/ article/2007/10/07/AR2007100701212.html.
} 
The next subsection investigates the revisions that were made to privatised diplomatic security in response to the scandals reviewed above.

\section{Privatised Diplomatic Security Reformed}

In the wake of the Nisour Square scandal, several measures were enacted to reform Us diplomatic security policies and improve the accountability of US State Department contractors and PSCs in general. Already in 2004, the Us Congress had amended the Military Extraterritorial Jurisdiction Act, extending it to contractors working for the Department of Defense and other agencies 'to the extent such employment relates to supporting the mission of the Department of Defense'. In 2007, the us Uniform Code of Military Justice was also revised to extend military jurisdiction to civilians accompanying an armed force in the theatre of a contingency operation. ${ }^{70}$

After Nisour Square, the State Department's Bureau of Diplomatic Security also devised some additional measures to increase the accountability of PSCs, installing cameras on contractors' vehicles and hiring new personnel in charge of accompanying private security motorcades and to monitor their performance. ${ }^{71}$ The WPPS contract, however, did not face major reforms. While a performance evaluation report acknowledged a 'loss of confidence' in Blackwater, it also recommended that the same PSC be used again as a government contractor. ${ }^{72}$ In 2008, Blackwater's us Embassy in Baghdad task order was indeed extended for yet another year. ${ }^{73}$ Only in 2009 , because of persistent public uproar and pressure from the White House, the State Department announced that its contracts with Blackwater would not be renewed. ${ }^{74}$ The outsourcing of us diplomatic security, however, did not decrease. Even in the wake of the Nisour Square incident, us State Department personnel firmly maintained that the use of PSCs was indispensable. As stated by then Ambassador to Iraq Ryan Crocker before the Senate Armed Services Committee, 'There is simply no way at all the State Department's Bureau of Diplomatic Security could ever have enough full-time personnel to staff the security function in

70 Mirko Sossai, "The Legal Framework for the Armed Forces and the Regulation of Private Security', in Rita Abrahamssen and Anna Leander (eds), The Routledge Handbook of Private Security (London: Routledge, 2015).

71 Laura Dickinson, Outsourcing War and Peace (New Haven, ст: Yale University Press, 2011).

72 Us State Department, 'Contractor Past Performance Evaluation', available online at http:// psm.du.edu/media/documents/us_regulations/state/state_dept_contract_past_perform_ review/us_state_contractor_performance_review_blackwater.pdf. в вс, 'Blackwater Iraq Contract Renewed' (5 April 2008), available online at http://news .bbc.co.uk/2/hi/7331972.stm.

74 Author's interview with private security industry representative. 
Iraq. There is no alternative except through contracts'. ${ }^{75}$ In 2010, the Worldwide Protective Service Contract was therefore re-awarded for the third time. The third iteration of the programme - now shortened to Worldwide Protective Security (WPS) - covers both static and mobile security and involves eight different PSCs, which can compete for individual task orders in order to ensure greater competition (see Table 3).

However, problems persisted. The first contract for the protection of the us Embassy in Kabul, which had initially been awarded to ArmorGroup, was terminated in 2009 after a Us Senate investigation revealed that contractors' misconduct repeatedly placed the security of the us Embassy at risk, and the contract was then re-awarded to ЕОDT. The new security provider, however, was also charged with insufficient staffing numbers, as well as poor training

TABLE 3 Us State Department worldwide (personal) protective security contracts

\begin{tabular}{lll}
\hline & Providers & Period \\
\hline WPPS I & Dyncorp International ${ }^{76}$ & $2005^{-2010}$ \\
WPPS II & Dyncorp International & $2005^{-2010}$ \\
& Blackwater Worldwide ${ }^{77}$ & \\
& Triple Canopy, Inc. & \\
& Aegis Defense Services & \\
WPS (WPPS III) & DynCorp International & \\
& EOD Technology (EODT) \\
& Global Integrated Security \\
& International Development Solutions \\
& soc \\
& Torres International \\
& Triple Canopy, Inc. & \\
\end{tabular}

75 Blackwater Hearing, p. 123. All of the us State Department personnel interviewed by the author concurred with this statement.

76 Blackwater was also involved in the protection of the Us Embassy in Baghdad in 2004 because of Dyncorp's inability to meet the us State Department's requests.

77 Blackwater's involvement was terminated in 2009 . 
and vetting policies. When the us State Department terminated the EODT task order, the firm sued the us government, which was forced to pay compensation for breaking the contract. ${ }^{78}$ In 2011, protection of the Us Embassy in Kabul was reassigned for the third time in three years to the British PSC Aegis under Task Order 10. As of April 2014, Task Order 10 involved 933 contracted personnel, for a total cost of Us $\$ 723$ million over a five-year period. Even after being reassigned for the third time, however, the security contract for the Kabul US Embassy remained contentious. In 2014, the State Department InspectorGeneral's Office of Audits also raised some issues concerning Aegis's screening of guards and staffing levels, and questioning unsupported costs of us $\$ 8$ million that had been charged by the contractor. ${ }^{79}$

The conduct of security of movement, logistics and emergency medical support for us State Department personnel in Baghdad, on the other hand, was awarded to Triple Canopy, which took over the tasks that had previously been performed by Blackwater and absorbed many of Blackwater's personnel. Task Order 5 involves no fewer than 500 personnel and will be worth $\$ 1.5$ billion USD upon completion. While us State Department auditors found Triple Canopy's performance to be adequate, they also noted that the contractor's staffing levels and invoices contained unallowable, unsupported and erroneous costs, thereby resulting in wasteful spending. ${ }^{80}$

The incident that occurred in Benghazi, Libya, in 2012 also revealed serious problems with the use of local contractors as diplomatic security providers. The perimeter of the villa that had been rented by the us State Department in Benghazi was protected by guards working for a PSC already active in Libya, Blue Mountain Security, which had been hired through the Local Guards Program. The personnel of Blue Mountain, a small firm that was virtually unknown in the world of private security, largely consisted of untrained Libyans without any previous military or police background. Their loyalty was questionable too. A few months before the September 2012 attack, one guard was suspected of having thrown a homemade bomb into the us compound.

78 United States Department of State, 'Audit of the Department of State Process to Award the Worldwide Protective Services Contract', p. 12.

79 us State Department and the Board of Governors Office of Inspector General Office of Audits, 'Audit of Bureau of Diplomatic Security Worldwide Protective Services Contract Task Order 10 Kabul Embassy Security Force', AUD-MERO-15-03 (Washington, DC: us State Department, October 2014), p. 6.

80 Us State Department and the Broadcasting Board of Governors Office of Inspector General Office of Audits, 'Audit of Bureau of Diplomatic Security Worldwide Protective Services Contract Task Order 5 for Baghdad Movement Security' (Washington, DC: us State Department, January 2011), pp. 3-5. 
The size of the private security force protecting the compound was also deemed to be insufficient. While Blue Mountain executives repeatedly asked the us State Department to strengthen security around the compound, their requests fell on deaf ears. When the consulate was stormed, the guards securing the perimeter dispersed, proving unable to stop or delay the attack. ${ }^{81}$

As illustrated by the analysis conducted in this section, armed contractors have been crucial and yet problematic providers of diplomatic protection for the us State Department. The next section will analyse the causes for the growing use of PSCs to secure diplomatic embassies and premises.

\section{Analysing the Outsourcing of us Diplomatic Security}

The literature on security privatisation offers some insights into the rationale underlying the United States' increasing reliance on PSCs for diplomatic protection tasks. Advocates of privatisation have elaborated a functionalist explanation for the use of PSCs, conceptualising the increasing outsourcing of security as a response to new technological, operational and financial imperatives and arguing that outsourcing offers more effective security at reduced costs. ${ }^{82}$ The effectiveness of having diplomatic security performed by contractors, however, remains contentious. To be sure, PSCs have proved to be remarkably effective in ensuring the safety of us State Department officials in a difficult environment such as Iraq. Still, as observed above, this occurred at the price of creating considerable collateral damage and souring the relationship between Iraqis and Coalition forces. The Nisour Square incident, for instance, dramatically exacerbated the Iraqi insurgency, preventing us officials from leaving the Green Zone for several days, and is considered to be one of the grievances that made the Iraqi government reject the offer of a larger us military presence after the end of operation Iraqi Freedom in 2011. ${ }^{83}$ Moreover, contractors did not always prove capable of effectively guaranteeing the security of us diplomatic posts.

81 Mitchell Zuckoff, 13 Hours: The Inside Account of What Really Happened in Benghazi (New York: Twelve, 2014); and Tabassum Zakaria and Susan Cornwell, 'For Benghazi Diplomatic Security, us Relied on Small British Firm', Reuters (17 October 2012).

82 Christopher Kinsey and Malcolm Hugh Patterson, 'Introduction', in Christopher Kinsey and Malcolm Hugh Patterson (eds.), Contractors and War: The Transformation of United States' Expeditionary Operations (Stanford, cA: Stanford University Press, 2012), pp. 1-2; and Matthew R. Uttley, 'Private Contractors on Deployed Operations: The United Kingdom Experience', Defence Studies, vol. 4, no. 2 (2004), pp. 146-149.

83 McFate, The Modern Mercenary; Cusumano and Kinsey, 'Bureaucratic Interests and the Outsourcing of Security'. 
The case of the Us Embassy in Afghanistan, where contracted security services were repeatedly found to be inadequate and to have put the safety of the us Embassy at risk, is a case in point. Private protection of the us Special Mission to Benghazi also proved dramatically ineffective.

Budgetary constraints, manpower strains and the inability of government bureaucracies to hire and retain qualified personnel in an increasingly competitive job market, however, provide important insights into the increasing propensity to outsource security tasks. When confronted with Congressional criticism in the wake of the Blackwater scandal, us State Department officials justified resorting to contractors as a way to save us taxpayers' money, observing that the cost of deploying Blackwater contractors was much lower than the deployment of us military personnel or Diplomatic Security Service (DSS) agents. Blackwater's CEO Erik Prince also maintained a firm belief that the use of PSCs allows for significant cost-savings. When asked for evidence supporting this statement, however, Prince admitted that no such figures were available, and called for a 'great, fully burdened cost study that Congress could sponsor'. ${ }^{84}$ In the following years, two studies focusing on the cost-effectiveness of outsourcing diplomatic security were indeed conducted. Solid, incontrovertible evidence that outsourcing diplomatic protection allowed for large cost-savings, however, failed to materialise.

A study conducted in 2010 by the United States' Government Accountability Office focused on the comparative costs of contractors versus Dss agents. The evidence offered by the study was mixed. Tasks such as static security for diplomatic premises, which usually involve the use of cheaper third-country nationals or local guards, were found to be substantially cheaper when outsourced to contractors. By contrast, high-profile security services requiring highly experienced, American guards with a security clearance, such as the escorting of diplomatic motorcades, could have been performed more efficiently by the Dss. Over a one-year period, having diplomatic motorcades in Baghdad protected by DSs agents would have cost the Us taxpayers Us $\$ 240$ million, as opposed to the us $\$ 380$ million that was charged by Blackwater. ${ }^{85}$ As is often emphasised by advocates of private security, however, the us Diplomatic Security Service had neither a sufficient number of personnel nor the necessary expertise to protect all of the diplomatic motorcades that were transiting through Iraq. Performing diplomatic security in-house would hence have been impossible

84 Blackwater Hearing, p. 87.

85 United States Government Accountability Office, 'Warfighter Support: A Cost Comparison of Using State Department Employees versus Contractors for Security Services in Iraq' (Washington, DC: Government Printing Office, 2010). 
without first hiring and training large numbers of federal agents - a procedure that is both lengthy and expensive. Moreover, us State Department officials considered the ad-hoc, short-term hiring of a large number of contractors as more sensible than the permanent employment of a large number of Dss agents. The occupation of Iraq and Afghanistan was seen as an 'unusual mission [...] that begs for not creating a career position for foreign service helicopter pilots', ${ }^{86}$ as well as 'medics and armorers and mechanics'. ${ }^{87}$

The fact that such types of expertise abound in the us military, which had a large number of boots on the ground in both Iraq and Afghanistan, forcefully suggests that diplomatic security could be conducted by the us Department of Defense in both an effective and a cost-efficient fashion. Indeed, a study conducted in 2008 by the Congressional Budget Office found that the cost of Blackwater contractors was around us $\$ 10$ million higher than the detachment of 1.2 Us Army light-infantry units for diplomatic security assignments. ${ }^{88}$ While these considerations suggest that the us military could play a much larger role in providing diplomatic security in the context of large military operations such as Iraq and Afghanistan, long-standing inter-agency cooperation difficulties and diverging organisational cultures inhibited the use of military personnel for the performing of diplomatic security tasks. The us State Department's preference for contractors over military personnel partly stemmed from its willingness to retain full control of its own security. Already during the 1980s, when the attacks against the us Embassy in Beirut and the repeated information leaks from the us Embassy in Moscow called into question their ability to conduct diplomatic security effectively, us State Department officials 'fought hard and successfully' to keep diplomatic security competences and capabilities within the State Department. ${ }^{89}$ In Iraq, the State Department saw in the use of contractors a way to reduce its chronic dependence on the Us Department of Defense and to have security conducted according to its preferred standard operating procedures. In the initial phase of operation Iraqi Freedom, diplomatic protection was conducted by the us Army. The provision of diplomatic security, however, met with resistance from the us Department of Defense,

86 Blackwater Hearing, p. 87 .

87 Blackwater Hearing, p. 150.

88 Had us diplomatic security required two full us Army units on a rotational basis, however, having the us military perform diplomatic security might have become around us $\$ 12$ million more expensive than the use of Blackwater. See us Congressional Budget Office, 'Contractors' Support of us Operations in Iraq' (Washington, DC: us Congressional Budget Office, August 2008), p. 17.

89 Wilson, Bureaucracy, p. 183. 
which only committed to escorting high-ranking personnel. As a result, armed protection became a bone of contention among the State Department people, who came to feel that they didn't have enough security'. ${ }^{90}$ Moreover, military protection hampered the mobility of State Department personnel. When diplomatic protection was provided by the us military, State Department officials had no direct authority over their own escorts, had to arrange their movements in advance, and were unable to change itinerary and schedule. Private security contractors, who were obliged by contractual provisions to comply with their employer's requests, proved more suitable for us State Department needs, ensuring much greater mobility and flexibility for its personnel. ${ }^{91}$

Furthermore, military protection was seen as incompatible with the US State Department's preference for low-profile, civilian-looking security details. Already during the mid-1950s, the fact that us Marines had to perform their duties in uniform reportedly created friction between the Corps and the Foreign Service, which insisted on the need for embassy guards to have a more civilian appearance in order to integrate us diplomatic posts better into their host societies and to accommodate the preferences of local authorities. ${ }^{92}$ In Iraq, too, us State Department officials found the use of military uniforms and vehicles problematic. When asked whether the us military could perform diplomatic security in the wake of the Nisour Square incident, then Assistant Secretary of State for Diplomatic Security Richard Griffin acknowledged that 'the Army would be capable of doing it if it was done in the manner which we prescribed, which would not be Humvees, they would not be in uniforms [...]' As further explained by Griffin:

What you want is a low profile. You want a protocol that says you don't bring in tanks, you bring in a civilian car, you want people dressed in civilian clothes for the most part, not dressed in Army uniform. [...] When Mr Bremer went into places, wasn't one of the criticisms that he was going in with the Army, having an Army footprint instead of having a civilian footprint? ${ }^{93}$

Dickinson, Outsourcing War and Peace, p. 37. See also Thomas Bruneau, Patriots for Profit: Contractors and the Military in Us National Security (Stanford, CA: Stanford University Press, 2011).

91 Interview with DSs agent.

92 us State Department, The History of the Bureau of Diplomatic Security, pp. 102-103.

93 Blackwater Hearing, pp. 148, 167. 
In sum, while the us military was in principle capable of providing diplomatic security, the us State Department's preference was for contractors, because they could provide low-profile civilian-looking security details. To be sure, the us military was no more supportive of detaching some of its personnel in order to perform diplomatic security. The combat-oriented organisational culture of the us military, which has displayed a long-standing wariness of seconding its personnel to other agencies for functions that are seen as peripheral, led the Department of Defense to consider the provision of diplomatic security as an unwelcome task. As stated in a 2007 report, 'The us Military in Iraq does not consider it feasible or desirable under existing conditions in Iraq for the Department of Defense to take on responsibility for provision of protection support to the Embassy'. ${ }^{4}$

As explained in this section, the United States' approach to the outsourcing of diplomatic security was shaped by a host of different factors. Financial considerations, manpower shortages and organisational interests and cultures - combined with the soaring demand for protection imposed by the deployment of State Department personnel in dangerous locations - converge in explaining why the United States' reliance on contractors has increased enormously over the last two decades and will remain a key component of us diplomatic security in the foreseeable future. The concluding section will draw on the analysis conducted so far to offer some policy recommendations on the future use of contractors as providers of diplomatic security for the us State Department and other states' foreign service personnel alike.

\section{Implications and Conclusions}

Far from decreasing in the wake of recent scandals, the United States' tendency to outsource diplomatic security has consolidated and expanded to other countries. As mentioned in several policy documents, and further stressed by the personnel who were interviewed by the author, replacing contracted personnel with Dss agents would be unfeasible. ${ }^{95}$ Local and international PSCs are and will remain crucial to allow the us State Department to conduct diplomatic activities in dangerous environments. The occurrences of abuse, poor performance and wasteful spending, however, have cast doubts over the

\footnotetext{
94 Report of the Secretary of State's Panel on Personal Protective Services in Iraq (Washington, DC: October 2007), p. 5.

95 Blackwater Hearing; author's interview with regional security officer; author's interview with retired us ambassador; and author's interviews with retired Dss agents.
} 
appropriateness of State Department diplomatic security practices in the wake of the occupation of Iraq and Afghanistan, carrying policy lessons of crucial importance in order to improve the efficiency, effectiveness and accountability of PSCs protecting diplomatic personnel and premises.

First, establishing tight monitoring mechanisms is paramount in order both to ensure an effective protection of diplomatic personnel and premises and to guarantee that contractors' activities do not degenerate into fraud, abuse against locals and human rights violations. The security vacuum created by the explosion of sectarian violence and the rise of the insurgency in Iraq caught both the us State Department and the Department of Defense by surprise. As a result, the systematic use of PSCs occurred in a largely ad-hoc fashion, often without any pre-planning and with little or no accountability mechanisms in place. The shortage of contracting officers and regional security officers inevitably translated into insufficient monitoring of the us State Department's security contractors. Only in 2009, in response to the Nisour Square incident, was the position of Security Protective Specialists (specifically tasked with accompanying security guards in their movements in order to ensure the appropriate oversight) created within the State Department. As Diplomatic Security Bureau personnel remain stretched thin, however, Security Protective Specialists have engaged in a broader range of tasks, including the general management of diplomatic security arrangements at large. ${ }^{96}$

Relatedly, the presence of clear mechanisms that ensure the legal liability of private security personnel is crucial. While armed contractors are usually accountable under the host state's law, PSCs operating in Iraq were exempted from Iraqi jurisdiction by Coalition Provisional Authority Order 17, and later included into the Status of Forces Agreement between the United States and Iraq. ${ }^{97}$ While contractors were exempt from Iraqi jurisdiction, their prosecution under us law was also problematic because of the lack of appropriate legal mechanisms. us legislation eventually caught up by including contractors into the Military Extraterritorial Jurisdiction Act and the Uniformed Code of Military Justice, but problems may still arise when contractors operate in states with a weak law enforcement capacity. As extraterritorial jurisdiction is hampered by challenges such as collecting evidence and summoning witnesses from foreign countries, the possibility of prosecuting contractors under

96 us Department of State, 'Security Protective Specialists', available online at http://www .state.gov/m/ds/career/c28469.htm.

97

Jennifer Elsea, Moshe Schwartz and Kennon Nakamura, 'Private Security Contractors in Iraq: Background, Legal Status, and Other Issues', Report for Congress (Washington, DC: Congressional Research Service, 2008), pp. 14-16. 
us law may provide a response to abuses of such outstanding gravity as the Nisour Square incident, but cannot fully replace host countries' criminal justice systems. ${ }^{98}$

Second, while ensuring the legal liability of individual contractors under the host nation's and contracting state's law is fundamental, foreign ministries such as the us State Department should also fully support the existing international regulatory frameworks, which were established in order to increase accountability and incentivise professionalism among private security providers. The so-called Swiss Initiative on the regulation of private military and security companies, for instance, led to the drafting of the International Code of Conduct (ICoC), committing signatory companies to high professionalism, strict training, vetting procedures and respect for human rights. In September 2013, the International Code of Conduct Association (ICoCA) was created to monitor companies' compliance with the ICoC and to hear grievances concerning violations. Following completion of the ICoC in 2010, the US Department of Defense also relied on Asis International, the main securityrelated standards drafting organisation, to develop formal standards for PSCs based on the principles laid out by the ICoC. To date, four different standardisation codes helping firms translate compliance with human right principles into their business practices have been drafted. In order for these voluntary initiatives to be successful, commercial incentives rewarding those PSCs that abide by existing regulatory initiatives are key. Large consumers of private security such as the us State Department should hence reward compliance with these frameworks by only hiring those firms that have signed the ICoCA and follow AsIs International's standards. While the us State Department supported the launch of these regulatory initiatives, it has been slow in awarding diplomatic security contracts consistently, announcing only in 2014 that compliance with ASIS International's standards and ICoCA membership will be considered compulsory for companies that seek to be awarded diplomatic protective task orders within the framework of the next wPS contract. ${ }^{99}$ The Local Guards Program, by contrast, does not contain any provisions obliging

98 Eugenio Cusumano, 'Policy Prospects for Regulating Private Military and Security Companies', in Francesco Francioni and Natalino Ronzitti (eds.), War by Contract: Human Rights, Humanitarian Law and Private Contractors (Oxford: Oxford University Press), pp. $11-36$.

99 Ian Ralby, 'Accountability for Armed Contractors', Fletcher Security Forum (12 January 2015). 
the State Department to consider only ICoCA signatories as eligible. ${ }^{100}$ While smaller, local security firms may be unable to participate in major international regulatory initiatives, it is crucial that tight professional and ethical standards are reflected in all decisions about awarding contracts. As local PSCs are hired based on a lowest acceptable price rather than a best value criterion, their compliance with ethical business practices may not be taken sufficiently into account when assigning contracts. In 2010, following some recommendations made by the Commission on Wartime Contracting, the Consolidated Appropriations Act required all us State Department security contracts in Iraq, Afghanistan and Pakistan to be awarded based on a best value reasoning. ${ }^{101}$ Local guard tenders in all other locations, however, still prioritise lowest price. Extending a best value rationale to all us State Department security contracts would ensure that criteria such as quality of training, past performance and the presence of credible codes of conduct are given prominence when hiring local guards to perform diplomatic security.

Third, while directly caused by contractors' misbehaviour, incidents such as Nisour Square were enabled by the problematic policy choices made by the us foreign service, Diplomatic Security Bureau and the us government at large. The rise of the Iraqi insurgency and the us State Department's determination to avoid any casualties among its personnel inevitably demanded tight, proactive, security measures. However, the drafting of permissive firearms policies that allowed civilian contractors who were subjected to unclear accountability mechanisms to use deadly force pre-emptively and discretionally was a recipe for disaster. The high visibility of us State Department motorcades exacerbated the problems. As observed by Blackwater's Chief Executive Officer Erik Prince, the fact that 'State wanted its diplomats charging through Baghdad in gunned-up convoys as waxed SUVs bristling with antenna arrays' was a show of authority that 'would practically taunt insurgents to strike'.102 Reconciling mobility by high-profile convoys with effective commercial security for us State Department personnel had only proved to be possible at the price of significant collateral damage among locals. As a result, Pscs in Iraq partly undermined the success of the diplomatic activities that they enabled, creating

\footnotetext{
100 United States Department of State and the Broadcasting Board of Governors Office of Inspector General Office of Audits, 'Review of Best-Value Contracting for the Department of State Local Guard Program'; and author's interview with retired special agent.

101 United States Department of State and the Broadcasting Board of Governors Office of Inspector General, 'Semiannual Report to the Congress' (Washington, DC: us State Department, May 2012), p. 18.

102 Prince, Civilian Warriors, p. 156.
} 
grievances among the Iraqi government and the local population. Devising truly effective diplomatic protective policies therefore also requires a careful assessment of whether certain security arrangements are compatible with the local environment, how they are perceived by host populations, and what their impact is on the relationship between sending states and local societies.

While us diplomatic security policies in Iraq were fundamentally problematic, most current and future instances of privatised diplomatic security will occur in less-hostile environments and will entail less-sensitive tasks, such as perimeter security for us embassies and consulates operating in more stable environments with a functioning judiciary and law enforcement sector. In such cases, a tightly regulated choice of reputable PSCs - complying with the relevant regulatory initiatives and subjected to adequate supervision - can provide a useful complementary source of diplomatic security for both the us State Department and other foreign services, thus helping to ensure the safety of diplomatic personnel worldwide.

Eugenio Cusumano is Assistant Professor in International Relations at the University of Leiden and a Fellow at the NATO Centre for Civil-Military Cooperation (CCOE). Prior to moving to the Netherlands, he was a Lecturer at the Baltic Defence College in Tartu, Estonia, and a Fulbright Scholar at the Korbel School of International Studies in Denver, co, in the United States. His research, which has been published in leading journals such as the Journal of Strategic Studies, International Relations, Armed Forces \& Society and International Peacekeeping, focuses on the increasing privatisation of military and security tasks, its causes and its political, strategic, legal and ethical implications. Dr. Cusumano is presently editing a volume that provides a comparative analysis of diplomatic security worldwide for Stanford University Press. 